\title{
Fitness Salonlarında Spor Yapan Bireylerin Egzersiz Bağımlılığı Düzeyleri ve ilişsili Değişkenler
}

\section{Exercise Addiction Levels of Individuals Exercising in Fitness Centers and Related Variables}

\author{
Recep Fatih Kayhan ${ }^{1}$ (D), Arslan Kalkavan ${ }^{1}$ (D), Esranur Terzi ${ }^{2}$ (ID) \\ 1. Recep Tayyip Erdoğan Üniversitesi, Beden Eğitimi ve Spor Yüksekokulu, Rize \\ 2. Recep Tayyip Erdoğan Üniversitesi, Sağlık Bilimleri Enstitüsü, Rize
}

\section{Abstract}

Objective: The aim of this study was to determine the symptoms of exercise dependence of individuals who do sports in fitness centers and to compare them in terms of certain variables.

Method: A total of 209 people, 94 men and 115 women, who regularly do sports in the fitness centers, voluntarily participated in the study. Exercise Dependence Scale-21 was applied to the athletes with the form in which personal information was questioned.

Results: There was a significant difference in exercise dependence sub-dimension levels of athletes according to gender, age, income level and number of training variables. When the symptoms of the participants are examined, 96 athletes participating in the study are described as asymptomatic and 113 as symptomatic. In our study, no athlete was identified as addicted. It was found that the risk of exercise dependence was highest in men, those between the ages of 18-22, those with an income between 3001-5000 TL, and those with a low number of training.

Conclusion: The athletes participating in our study were not exercise addicts but had risks, while the variables of gender, age, income and number of training could be effective in the emergence of exercise dependence symptoms. It is thought that support should be given to these athletes that a controlled, balanced and correct exercise program would be more efficient instead of excessive exercise.

Keywords: Addiction, leisure time, exercise, recreation, sport

Öz

Amaç: Bu çalışmada fitness salonlarında spor yapan bireylerin egzersiz bağımllı̆̆ı semptomlarını tespit ederek belirli değiş̧kenler açısından karşılaştırmak amaçlanmışıır.

Yöntem: Çalışmaya fitness salonlarında düzenli olarak spor yapan 94 erkek, 115 kadın toplamda 209 kişi gönüllü olarak katılmışıır. Sporculara kişisel bilgilerin sorgulandığı form ile Egzersiz Bağımlıı̆ı Ölçeği-21 uygulanmıştır.

Bulgular: Cinsiyet, yaş, gelir düzeyi ve antrenman sayısı değişkenine göre sporcuların egzersiz bağımlı̆ı̆ı alt boyut düzeylerinde anlamlı bir fark bulunmuştur. Sporcuların göstermiş olduğu semptomlar incelendiğinde çalışmaya katılan 96 sporcu asemptomatik, 113 sporcu ise semptomatik olarak nitelendirilmektedir. Çalışmamızda bağımlı olarak nitelendirilen sporcu tespit edilmemiştir. Katılımcılarda egzersiz bağımlı̆ı̆ı riskinin en fazla erkekler, yaşı 1822 yaş arasında olanlar, 3001-5000 TL arasında gelire sahip olanlar ve antrenman sayısı az olanlarda olduğu tespit edilmiştir.

Sonuç: Çalışmamıza katılan sporcuların egzersiz bağımlısı olmadıkları fakat risk taşıdıkları görülürken cinsiyet, yaş, gelir ve antrenman sayısı değişkenlerinin egzersiz bağımlı̆̆ı semptomlarının ortaya çıkmasında etkin olabileceği görülmektedir. Bu sporculara aşıı egzersiz yerine kontrollü, dengeli ve doğru bir egzersiz programının daha verimli olacağı konusunda destek verilmesi gerektiği düşünülmektedir.

Anahtar kelimeler: Aktivite, bağımlılık, rekreasyon, spor 


\section{Giriş}

Çağdaş batı toplumlarında, 'fit vücut' hem erkekler hem de kadınlar için güçlü statü ve vücut uygunluğunun sembolü olarak yerini almıştır. Fitness salonları, böyle bir vücut tipine sahip olabilmek için kullanılmaktadır. Bu salonlar fiziksel formu düzenleyebilmek için eğlence amaçlı egzersizi amaçlayan, rekabet içermeyen ve içerisinde çeşitli egzersiz aletlerinin bulunduğu ortamlardır (1). Yapılan çalışmalarda, egzersizin fiziksel ve zihinsel gelişim üzerinde pozitif etkileri olduğu kanıtlanmasına rağmen aşırı düzeyde yapılan fiziksel aktivitenin egzersiz bağımlılığı gibi negatif etkilere sebep olabileceği de görülmüştür (1-3). Egzersiz rutinini, sıkıı̆ını ve şiddetini arttırmak, egzersiz yapabilmek için aile ve arkadaşlarla zaman geçirememe, sosyal aktivitelere katılmak yerine egzersiz yapma durumu egzersiz bağımlıığı olarak ifade edilmektedir ve birey fiziksel aktiviteye gereğinden fazla odaklanırken yaşamını egzersiz alışkanlıkları çerçevesinde şekillendirmektedir $(4,5,6)$. Birey egzersizi düzenli olarak gerçekleştirdiğinde, belli bir performansa ulaşabilmek için gerektiğinden fazla egzersiz yapmak için psikolojik bir baskı hissedebilmektedir. Yapılan egzersizde sürekli eksiklik hissediliyorsa ve bu istek artıyorsa bu durum kişi tarafından sorun haline getirilmektedir (7). Günümüzde egzersizi ciddiye alan ve hayatının önemli bir unsuru haline getiren birçok sağlıklı insanın bulunduğu da görülmektedir. Ancak egzersizle ulaşılamayan mükemmelliği hedefleyenler bağımlı olarak nitelendirilmektedir $(7,8)$.

Fiziksel aktivite, enerji harcamasını önemli ölçüde arttıran iskelet kasının kasılması ile üretilen bedensel hareket olarak tanımlanırken egzersiz terimi, fiziksel hareketin bir alt grubu olarak görülmektedir. Planlı, yapılandırımış ve tekrarlanan bedensel hareketler olarak tanımlanan egzersiz, fiziksel uygunluğun bir veya daha fazla unsurunu geliştirmek veya devam ettirebilmek için gerçekleştirilmektedir (9). Hem fiziksel aktivitenin hem de yapılandırımış egzersizin, bireylerin sağlığını ve yaşam kalitesini bağımsız olarak geliştirdiği görülmüştür. Ayrıca insanların depresyon ve anksiyete semptomlarını azaltarak psikolojik refahı artırmada etkili olduğu tespit edilmiştir (10). Hangi türdeki egzersizin, hangi sıklıkta, şiddette ve sürede gerçekleştirilirse maksimum yarar sağlayacağı, kesin olarak ortaya konulmasa da egzersizin kaygı, depresyon, stresle başa çıkma, beden algısı, ruh hali ve özgüven üzerinde pozitif etkileri olduğu görülmektedir (11). Egzersiz faydaları genel olarak insanların sağlığını korumak, bireyleri hastalıklardan uzak tutmak ve insanlara sağlıkı bir yaşam sunmak olarak sıralanabilmektedir $(12,13)$.

Araştırmacılar, egzersizi ıımlı miktarlarda sağlıklı bir yaşam tarzının önemli bir bileşeni olarak kabul ederken, aşırı düzeyde alındığında egzersizin bağımlılık yaratabileceğini belirtmişlerdir. Dengesiz bir biçimde egzersiz yapan kişi egzersiz yapmadığında anksiyete, depresyon, sinirlilik, uykusuzluk yaşamaktadır ve yaşamında karşılaşıı̆ı zorluklarla baş etmek için egzersiz yapmaktadır (14). Egzersiz bağımlıları, psikolojik işlev bozukluğu, fiziksel yaralanma ve sosyal ilişkilerde sorunlarla karşılaşabilirler (15). Egzersiz sürecinde ise fizyolojik belirtiler (tolerans, kaçınma) veya psikolojik belirtiler (depresyon, gerginlik) ile kendini göstermektedir (16). Genellikle egzersiz bağımlıı̆ı riskinin, koşucular gibi belirli gruplar arasında daha belirgin olduğu bulunmuştur (17). Yapılan çalışmalarda kiloyu dengede tutmak, iyi görünmek ve beden motivasyonunu artırmak için yapılan aşırı egzersizlerin bağımlılık yaptığı görülmüştür (18-20).

Yapılan taramalar literatürde fitness salonlarında spor yapan bireylerin egzersiz bağımlı̆ı̆ı semptomlarına sahip olup olmadıklarını belirlemek amacıyla yapılmış bir çalışmanın olmadığını göstermektedir. Daha önceki araştırmalarda da görüldüğü gibi egzersiz yapan kişilerin bağımlıık düzeylerinin ortaya konması birey, aile ve toplum sağıı̆ı açısından oldukça önemli olmaktadır. Egzersiz içerisinde olan kişiler zamanla egzersize katımayı ailesel veya diğer sosyal ilişkilerden daha çok önemsemekte ve ön planda tutmakta hatta ileri zamanlarda bu durum bireyin kontrollünden de çıkabilmektedir. Alkol, ilaç, sigara vs. bağımlılık türleri gibi egzersiz bağımlılığı da hem psikolojik hem de fizyolojik bir sorun olarak bakılmaktadır. Egzersiz bağlı̆ğını etkileyen unsurları belirlemek ve egzersiz bağlıı̆̆ını kontrol etmede kullanılan yöntemleri anlayarak bu yöntemleri bireysel olarak uygulayabilmek sağlıklı yaşam alışkanlığı sağlamada ve sürdürmede önemli olmaktadır. Bu sebeple böyle bir durumun bireyin hayatını etkilemeden önce tespit edilmesi ve gerekli tedbirlerin alınması önemli olmaktadır. Bu bağlamda, bu çalışmanın amacı fitness 
salonlarında spor yapan bireylerin egzersiz bağımlılığı düzeylerinin araştıııması ve değişkenler açısından karşılaştııılarak ortaya konmasıdır. Çalışma; cinsiyet, yaş, antrenman sayısı, gelir durumu ve eğitim durumu sporcuların egzersiz bağımlıı̆ı düzeyleri üzerinde farklıık yaratır hipotezleri doğrultusunda şekillenmiştir.

\section{Yöntem}

Bu çalışma betimsel yöntem ve ilişkisel tarama modeline göre şekillenmiştir. Buna göre çalışmada yer alan katılımcılardan veri toplanarak, görüşlerine başvurulmuştur. Bu doğrultuda fitness salonunda spor yapan sporcuların egzersiz bağımılı̆̆ı düzeylerinin belirlenmeye çalışılığı bu çalışma betimsel tarama modeline dayanmaktadır.

\section{Örneklem}

Araştırmanın çalışma grubunu fitness salonlarında düzenli olarak çalışma yapan yaşları ortalaması 25,94 $\pm 5,11$ olan 94 erkek, 115 kadın toplamda 209 katıımc oluşturmaktadır. Anket formu Google Doc olarak internet araclığıyla sporculara gönderilmiştir ve veriler elde edilmiştir. Çalışmaya son altı ay içerisinde herhangi bir fiziksel ve psikolojik rahatsızlık yaşamayan 18 yaş üstü gönüllü bireyler dahil edilmiştir. Bireylere çalışmaya katılmama veya katılıktan sonra herhangi bir anda çalışmadan çıkma hakkına verilmiştir.

\section{İşlem}

Bu çalışmadaki verileri elde edebilmek için araştırmacı tarafından oluşturulan kişisel özelliklerin belirlendiği form ve Egzersiz Bağımılı̆̆g Ölçeği-21 kullanıımıştır. Bu ölçüm araçlarına ilişkin protokoller aşağıda belirtilmiştir. Bu araştırma protokolü Recep Tayyip Erdoğan Üniversitesi Sosyal ve Beşeri Bilimler Etik Kurulu (sayı: 2021/34, Tarih: 16/02/2021) tarafından onaylanmıştır Bu araştırma Helsinki Bildirgesi'ne uygun olarak yürütülmüştür. Tüm katıımcılardan yazılı bilgilendirilmiş onam alınmışıır.

\section{Veri Toplama Araçları \\ Demografik Anket Formu}

Araştırmacı tarafından hazırlanan katılımcıların cinsiyet, yaş, eğitim düzeyi, gelir durumu ve haftalık antrenman sayısı sorularından oluşmaktadır. Çalısmamızda gelir durumu gruplandırması asgari ücrete göre ve kişilerin dağılımlarına göre şekillenmiştir.

\section{Egzersiz Bağımlıı̆ı Ölçeği-21}

Hausenblas ve Downs (2002) tarafından, toplamda 2420 kişilik bir örneklem grubu kullanılarak, beş aşamada geliştirildi (21). Ölçeğin Türkçeye uyarlanma çalışması Yeltepe ve İizler (2007) tarafından yapılmıştır. Gerçekleştirilen test-tekrar test analizlerinde $p<0,001$ düzeyinde istatistiksel olarak anlamlılık bulunmuş ve Cronbach alfa değeri $p=0,95$ olarak hesaplanmıştır. Ölçek formu, 18 yaş ve üzerinde bireylere uygulanabilmektedir. Asla (1) ve daima (6) olacak şekilde 6'I Likert tipindedir. DSM-IV'ün madde bağımlılık faktörleri temel alınarak hazırlanan ve 21 sorudan oluşan EBÖ-21'in ölçek sonucundan elde edilen bulgulara göre bağımlılık durumları tespit edilerek bireyler; 5-6 puan aralığı bağımlı, 3-4 puan aralı̆ı bağımlı olmaya aday (semptomatikler) ve 1-2 puan aralığı bağımlı olmayan (asemptomatikler) şeklinde üç ayrı grupta değerlendirilmektedir (22). Ölçekten alınabilecek en düşük puan 21, en yüksek puan 126'dır. Egzersiz Bağımlıı̆̆ı Ölçeği-21 5 alt boyuttan oluşmaktadır.

1. Zaman ve Egzersiz Tercihi

2. Kontrol Edememe

3. Geri Çekilme

4. Tolerans

5. Devamlllik (22).

Egzersiz Bağımlılı̆ı Ölçeği bize alt boyut ve egzersiz bağımlılı̆ı semptomları (bağımlı, bağımlıık riski taşıyan ve bağımlı olmayan) puanlarının ortalamaları ile ilgili bilgileri verir. Çalışmamızda egzersiz bağımlıı̆ı 
ölçeği için toplanan verilerin Cronbach's Alpha iç tutarlıık katsayısı 0.870 olarak tespit edilmiştir ve bu örneklem üzerinde kullanılabileceği belirlenmiş̧tir.

\section{Veri Analizi}

Verilerin çözümlenmesi aşamasında SPSS 26 lisanslı paket programı kullanılmıştır. Verilerin dağılımını belirlemek amacıyla yapılan normallik testi sonucunda (23), verilerin normal dağıldığı tespit edilmiştir. Veriler normal dağııma sahip olduğundan parametrik testler kullanılmıştır. Cinsiyet, eğitim durumu ve haftalık antrenman sayısı değişkenleri ile egzersiz bağımlı̆̆ı düzeylerinin karşılaştırımasında T-testi; yaş ve gelir durumu değişkenleri ile egzersiz bağımlıı̆ı düzeylerinin karşılaşııılımasında Tek Yönlü Anova testi kullanılmıştır. Anova testi sonrasında farkılıkları belirlemek üzere tamamlayıcı post-hoc analizi olarak Tukey testi kullanılmıştır. Analizlerde anlamlılık düzeyi $p<0,05$ olarak belirlenmiştir.

\section{Bulgular}

Sporcular cinsiyete göre 94'ü (\%45) erkek, 115’i (\%55) kadın olarak dağılmaktadır. Yaşa göre 77’si (\%36,8) 18-22 yaş arası, 79'u (\%37,8) 23-28 yaş arası, 53'ü $(\% 25,4) 29$ yaş ve üstü olarak dağılmaktadır. Sporcuların 149'u (\%71,3) bekar, 60'ı (\%28,7) evlidir. Eğitim düzeyi üniversite 107 $(\% 51,2)$, lise $102(\% 48,8)$ kişi olarak dağılmaktadır. Sporcuların 40’ı $(\% 19,1)$ asgari ücret ve altı, 84'ü 3001-5000 TL arası, 85'si (\%40,7) 5001 TL ve üstü gelire sahiptir. 73 kişinin $(\% 34,9)$ haftalık antrenman sayısı 1-2, 136 kişinin $(\% 65,1)$ haftalık antrenman sayısı 3-4 arasındadır (Tablo 1=.

Tablo 1. Sporcuların demografik özellikleri

\begin{tabular}{|l|l|l|l|}
\hline \multirow{2}{*}{ Değişken } & Grup & $n$ & $\%$ \\
\hline \multirow{2}{*}{ Cinsiyet } & $18-22$ yaş & 77 & 36,84 \\
\cline { 2 - 4 } & $23-28$ yaş & 79 & 37,80 \\
\cline { 2 - 4 } & 29 yaş ve üstü & 53 & 25,36 \\
\hline \multirow{2}{*}{ Medeni Durum } & Erkek & 94 & 44,98 \\
\cline { 2 - 4 } & Kadın & 115 & 55,02 \\
\hline \multirow{2}{*}{ Eğitim Düzeyi } & Evli & 60 & 28,71 \\
\hline \multirow{2}{*}{ Gelir Durumu } & Bekar & 149 & 71,29 \\
\hline & Lise & 102 & 48,80 \\
\cline { 2 - 4 } & Üniversite & 107 & 51,20 \\
\hline \multirow{2}{*}{ Haftalık Antrenman Sayısı } & Asgari ücret ve altı & 40 & 19,14 \\
\cline { 2 - 4 } & $3001-5000$ TL & 84 & 40,19 \\
\cline { 2 - 4 } & 5001 TL ve üstü & 85 & 34,67 \\
\hline & $1-2$ & 73 & 65,03 \\
\hline
\end{tabular}

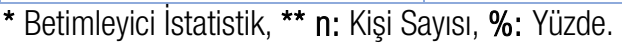

\section{Tablo 2. Sporcuların egzersiz bağımlılı̆ı düzeyleri}

\begin{tabular}{|l|c|c|}
\hline Değışken & $n$ & $\%$ \\
\hline Bağımlı Olmayan & 96 & 45,9 \\
\hline Bağımılıık Riski Taşıyan & 113 & 54,1 \\
\hline
\end{tabular}

* Betimleyici İstatistik, ${ }^{\text {** }} \mathrm{n}$ : Kişi Sayısı, \%: Yüzde.

Çalışmada 96 sporcu asemptomatik, 113 sporcu ise semptomatik semptom taşımaktadır (Tablo2 ). Fitness salonlarında spor yapan sporcuların cinsiyetleri açısından egzersiz bağımlıı̆ı alt boyut düzeylerinde anlamlı fark olup olmadığını belirlemek için $p<0,05$ anlamlılık düzeyinde bağımsız iki grup için t-testi uygulandı. Test sonuçlarında cinsiyetleri bakımından fitness yapanların devamlılık alt boyutunda $\left(\mathrm{t}_{(207)}=4,48 ; p<0,05\right)$ ve toplam puanlarında $\left(t_{(207)}=-2,09 ; p<0,05\right)$ anlamlı fark tespit edilirken zaman ve egzersiz tercihi, kontrol edememe, geri çekilme ve tolerans alt boyut düzeylerinde anlamlı fark tespit edilmemiştir $(p>0,05)$. Devamlılık alt boyutunda $(X=3,45 \pm 0,71)$ ve toplam puanda $(X=3,02 \pm 0,30)$ erkeklerin ortalamaları, kadınların ortalamalarından anlamlı şekilde daha yüksektir. 


\begin{tabular}{|c|c|c|c|c|c|c|c|c|}
\hline 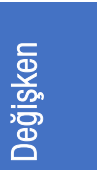 & \multicolumn{2}{|c|}{$\begin{array}{l}\text { Alt Boyut } \\
\text { Grup }\end{array}$} & $\begin{array}{c}\text { Zaman ve } \\
\text { Egzersiz } \\
\text { Tercihi }\end{array}$ & $\begin{array}{c}\text { Kontrol } \\
\text { Edememe }\end{array}$ & $\begin{array}{c}\text { Geri } \\
\text { Çekilme }\end{array}$ & Tolerans & Devamlillk & $\begin{array}{l}\text { Toplam } \\
\text { Puan }\end{array}$ \\
\hline \multirow{3}{*}{ 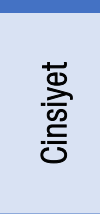 } & $\begin{array}{l}\text { Erkek } \\
(n=94)\end{array}$ & \multirow{2}{*}{$\begin{array}{l}\text { Ort. } \pm \\
\text { Ss }\end{array}$} & $2,66 \pm 0,30$ & $3,24 \pm 0,71$ & $3,00 \pm 0,73$ & $3,51 \pm 0,67$ & $3,45 \pm 0,71$ & $3,02 \pm 0,30$ \\
\hline & $\begin{array}{l}\text { Kadın } \\
(n=115)\end{array}$ & & $2,58 \pm 0,46$ & $3,18 \pm 0,66$ & $3,01 \pm 0,77$ & $3,51 \pm 0,66$ & $3,04 \pm 0,59$ & $2,93 \pm 0,37$ \\
\hline & p & & 0,138 & 0,542 & 0,907 & 0,979 & 0,000 & 0,038 \\
\hline \multirow{5}{*}{ 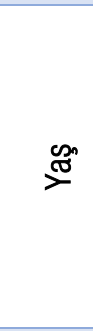 } & $\begin{array}{l}18-22 \text { yaş } \\
(\mathrm{n}=77)\end{array}$ & \multirow{3}{*}{$\begin{array}{l}\text { Ort. } \pm \\
\text { Ss }\end{array}$} & $2,69 \pm 0,39$ & $3,30 \pm 0,62$ & $2,97 \pm 0,87$ & $3,66 \pm 0,66$ & $3,38 \pm 0,62$ & $3,06 \pm 0,32$ \\
\hline & $\begin{array}{l}23-28 \text { yaş } \\
(n=79)\end{array}$ & & $2,59 \pm 0,34$ & $3,18 \pm 0,71$ & $3,00 \pm 0,67$ & $3,43 \pm 0,65$ & $3,00 \pm 0,63$ & $2,91 \pm 0,32$ \\
\hline & $\begin{array}{l}29 \text { yaş ve } \\
\text { üstü }(n=53)\end{array}$ & & $2,54 \pm 0,46$ & $3,11 \pm 0,71$ & $3,06 \pm 0,67$ & $3,42 \pm 0,65$ & $3,34 \pm 0,74$ & $2,93 \pm 0,38$ \\
\hline & $p$ & & 0,068 & 0,243 & 0,793 & 0,049 & 0,001 & 0,020 \\
\hline & Fark & & & & & $1>3$ & $1>2,3>2$ & $1>2$ \\
\hline \multirow{5}{*}{ 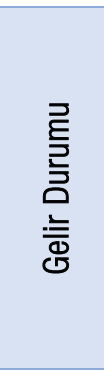 } & $\begin{array}{l}\text { Asgari ücret } \\
\text { ve altı } \\
(n=40)\end{array}$ & \multirow{3}{*}{$\begin{array}{l}\text { Ort. } \pm \\
\text { Ss }\end{array}$} & $2,58 \pm 0,37$ & $3,10 \pm 0,82$ & $2,74 \pm 0,61$ & $3,48 \pm 0,82$ & $3,16 \pm 0,70$ & $2,89 \pm 0,40$ \\
\hline & $\begin{array}{l}3001-5000 \\
T L(n=84)\end{array}$ & & $2,61 \pm 0,33$ & $3,26 \pm 0,56$ & $2,93 \pm 0,68$ & $3,55 \pm 0,57$ & $3,25 \pm 0,66$ & $2,97 \pm 0,26$ \\
\hline & $\begin{array}{l}5001 \mathrm{TL} \text { ve } \\
\text { üstü }(\mathrm{n}=85)\end{array}$ & & $2,63 \pm 0,46$ & $3,20 \pm 0,71$ & $3,20 \pm 0,83$ & $3,49 \pm 0,67$ & $3,24 \pm 0,69$ & $3,00 \pm 0,39$ \\
\hline & p & & 0,756 & 0,483 & 0,003 & 0,778 & 0,784 & 0,210 \\
\hline & Fark & & & & $3>1,3>2$ & & & \\
\hline \multirow{3}{*}{ 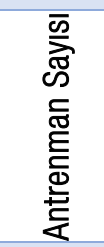 } & $1-2(n=73)$ & \multirow{2}{*}{$\begin{array}{l}\text { Ort.. } \\
\text { Ss }\end{array}$} & $2,61 \pm 0,41$ & $3,26 \pm 0,69$ & $3,02 \pm 0,72$ & $3,54 \pm 0,65$ & $3,42 \pm 0,68$ & $3,01 \pm 0,34$ \\
\hline & $3-4(n=136)$ & & $2,61 \pm 0,39$ & $3,18 \pm 0,67$ & $2,99 \pm 0,76$ & $3,50 \pm 0,67$ & $3,12 \pm 0,65$ & $2,95 \pm 0,34$ \\
\hline & \multicolumn{2}{|l|}{$p$} & 0,998 & 0,397 & 0,782 & 0,615 & 0,003 & 0,192 \\
\hline \multirow{3}{*}{ 点总 } & Lise $(n=102)$ & \multirow{3}{*}{$\begin{array}{l}\text { Ort. } \pm \\
\text { Ss }\end{array}$} & $2,66 \pm 0,36$ & $3,26 \pm 0,64$ & $2,98 \pm 0,83$ & $3,58 \pm 0,70$ & $3,29 \pm 0,59$ & $3,02 \pm 0,32$ \\
\hline & $\begin{array}{l}\text { Universite } \\
(n=107)\end{array}$ & & $2,57 \pm 0,42$ & $3,15 \pm 0,72$ & $3,02 \pm 0,66$ & $3,44 \pm 0,62$ & $3,16 \pm 0,75$ & $2,93 \pm 0,36$ \\
\hline & p & & 0,088 & 0,249 & 0,713 & 0,119 & 0,149 & 0,058 \\
\hline
\end{tabular}

* T-Testi, Anova Testi, Tukey Testi** n: Kişi Sayısı, Ort: Ortalama, Ss: Standart Sapma.

Fitness salonlarında spor yapan sporcuların yaşları açısından egzersiz bağımlılı̆ı alt boyut düzeylerinde anlamlı fark olup olmadığını belirlemek için $p<0,05$ anlamlılık düzeyinde Anova testi uygulandı. Test sonuçlarında yaşları bakımından fitness yapanların tolerans $\left(F_{(2.208)}=3,06, \quad p<0,05\right)$, devamlılık $\left(F_{(2.208)}=7,83 ; p<0,05\right)$ alt boyutlarında ve toplam puanlarında $\left(F_{(2.208)}=3,99 ; p<0,05\right)$ anlamlı fark tespit edilirken zaman ve egzersiz tercihi, kontrol edememe ve geri çekilme alt boyut düzeylerinde anlamlı fark tespit edilmemiştir $(p>0,05)$. Tolerans alt boyutunda 18-22 yaş arasındaki sporcuların ortalamaları $(X=3,66 \pm 0,66), 29$ yaş ve üstü sporcuların ortalamalarından; toplam puanda 18-22 yaş arasındaki sporcuların ortalamaları $(X=3,06 \pm 0,32), 23-28$ yaş arasındaki sporcuların ortalamalarından anlamlı şekilde daha yüksektir. Devamlıık alt boyutunda ise 23-28 yaş arasındaki sporcuların ortalamalarından $(X=3,00 \pm 0,63)$, diğer yaş gruplarından anlamlı şekilde düşüktür.

Fitness salonlarında spor yapan sporcuların antrenman sıklığı açısından egzersiz bağımlılı̆ı alt boyut düzeylerinde anlamlı fark olup olmadığını belirlemek için $p<0,05$ anlamlıık düzeyinde bağımsız iki grup için t-testi uygulandı. Test sonuçlarında antrenman sıklığı bakımından fitness yapanların devamlılık alt boyutunda $\left(\mathrm{t}_{(207)}=3,05 ; \mathrm{p}<0,05\right)$ anlamlı bir fark tespit edilirken zaman ve egzersiz tercihi, kontrol edememe, geri çekilme, tolerans alt boyut düzeylerinde ve toplam puanlarda anlamlı bir fark tespit edilmemiştir $(p>0,05)$. Devamllık alt boyutunda antrenman sayısı 1-2 arasında olan sporcuların 
ortalamaları $(X=3,42 \pm 0,68)$, antrenman sıkığı 3-4 olan sporcuların ortalamalarından $(X=3,12 \pm 0,65)$ anlamlı şekilde daha yüksektir.

Fitness salonlarında spor yapan sporcuların gelir durumları açısından egzersiz bağımlıı̆̆ alt boyut düzeylerinde anlamlı fark olup olmadığını belirlemek için $p<0,05$ anlamlılık düzeyinde Anova testi uygulandı. Test sonuçlarında gelir durumları bakımından fitness yapanların geri çekilme alt boyutunda $\left(F_{(2.208)}=6,10, p<0,05\right)$ anlamlı bir fark tespit edilirken zaman ve egzersiz tercihi, kontrol edememe, tolerans, devamlılk alt boyut düzeylerinde ve toplam puanda anlamlı bir fark tespit edilmemiştir $(p>0,05)$. Geri çekilme alt boyutunda 5001 TL ve üstü gelire sahip sporcuların ortalamaları $(X=3,20 \pm 0,83)$, asgari ücret ve altı gelire sahip sporcuların ortalamalarından $(X=2,74 \pm 0,61)$ ve 3001-5000 TL gelire sahip sporcuların ortalamalarından $(X=2,93 \pm 0,68)$ anlamlı şekilde daha yüksektir.

Fitness salonlarında spor yapan sporcuların eğitim durumları açısından egzersiz bağımlı̆̆g alt boyut düzeylerinde anlamlı fark olup olmadığını belirlemek için $p<0,05$ anlamlılı düzeyinde bağımsız iki grup için t-testi uygulandı. Test sonuçlarında eğitim durumu bakımından fitness yapanların egzersiz bağımlı̆̆ğı ölçeği alt boyut düzeylerinde ve toplam puanlarında anlamlı bir fark tespit edilmemiştir $(p>0,05)$.

\section{Tartışma}

Sporcuların göstermiş olduğu semptomlar incelendiğinde çalışmaya katılan 96 sporcu asemptomatik (bağımlılık göstermeyen), 113 sporcu ise semptomatik (egzersiz bağımlılı̆ı riski taşıyan) olarak nitelendirilmektedir. Çalışmamızda bağımlı olarak nitelendirilen sporcu tespit edilmemiştir. Nitekim yapılmış araştırmalar incelendiğinde dayanıklılık içeren spor dallarında ve ağırlık sporlarında egzersiz bağımlıı̆̆ı riski içerisinde olan sporculara görülmüştür $(30,41)$. Yapılan araştırmalar incelendiğinde aerobik egzersizlerde bağımlıık riskinin fazla olduğu tespit edilmiştir $(42,43)$. Yeltepe'nin sporlar üzerine yaptığı çalışmasında egzersiz bağımlılık riski taşıyan bireylerin kürek sporlarında yoğunlaştığı görülmüştür (27). Bingöl, sporcular üzerine yapmış olduğu bir çalışmada güreş branşında bağımlılık riski taşıyanların sayısının fazla olduğu gözlenirken, futbol branşında egzersiz bağımlııı riski taşıyanların sayısının az olduğu tespit edilmiştir (26).

Cinsiyet açısından egzersiz bağımlıığı toplam puanında ve devamlıık alt boyutunda erkek sporcuların, kadın sporculardan anlamlı şekilde daha çok egzersiz bağımlıığı riski taşıdığı görülmüştür. Buna var olan sosyal alanların istenilen düzeyde ve kadınların ilgi alanlarına yönelik olmamasının sebep olduğu düşünülebilir. Literatür incelendiğinde cinsiyete göre egzersiz bağımlıığının değiştiği görülmektedir. Yapılan çalışmaların bazılarında egzersiz bağımlıı̆ı riskinin erkeklerde fazla olduğu görülürken bazı çalışmalarda egzersiz bağımlıı̆ı riskinin kadınlarda fazla olduğu görülmektedir $(24,25)$. Bingöl, sporcular üzerine yapmış olduğu bir çalışmada erkeklere göre kadınların sayısının daha az olmasına rağmen egzersiz bağımlıık riski taşıyanların sayısının erkeklere yakın olduğunu ve cinsiyetin egzersiz bağımlılı̆ı üzerinde bir etkisinin olmadığını tespit etmiştir (26). Yeltepe, yaptığı çalışmada bizim çalışmamızdan farklı olarak cinsiyet açısından egzersiz bağımlıık düzeylerinde anlamlı fark olmadığını belirlemiştir (27). Vardar' da yaptığı çalışmada cinsiyet açısından anlamlı fark belirlememiştir (28). Hailey ve Bailey, yaptıkları bir çalışmada erkelere göre kadınların daha fazla egzersiz bağımlıı̉ riski taşıdığını tespit etmişlerdir (29). Yapılan bir başka çalışmada, kadınların erkeklere oranla daha yüksek egzersiz bağımlılık puanına sahip oldukları belirlenmiştir (30). Yapılan diğer çalışmalarda da egzersiz bağımlılığı ile cinsiyet arasında anlamlı farklılık bulunmamıştır (30-32). Bu araştırmaların mevcut çalışmadan farklılık göstermesinin çalışma gruplarından kaynaklandığı düşünülmektedir.

Yaş açısından egzersiz bağımlılığı toplam puanında ve tolerans, devamlılık alt boyutlarında 18-22 yaş arasındaki sporcuların anlamlı şekilde daha çok egzersiz bağımlılığı riski taşıdığı görülmüştür. Yaşı küçük olan sporcuların egzersize daha çok vakit ayırdıkları ve egzersizi amaçlanandan daha çok gerçekleştirmek istedikleri söylenebilir. Egzersiz bağımlılığı riski taşımalarına da tecrübe konusunda yaşı büyük olan sporculara göre daha az bilinçli olmaları ve antrenman programlarının doğru şekilde uygulanmamasının neden olacağı düşünülmektedir. Literatür incelendiğinde Cicioğlu ve ark., elit düzeyde sporcuların yaşlarına göre egzersiz bağımlıık düzeylerinde anlamlı bir ilişki tespit etmişlerdir (3). Çalışmamızdan farklı olarak ise 
bir çalışmada farklı spor dallarındaki sporcuların yaşları ile egzersiz bağımılıı puanları arasında anlamlı fark görülmemiştir (45). Yapılan diğer çalışmalarda da sporcuların yaşları ile egzersiz bağımlılık düzeyi arasında anlamlı fark tespit edilmemiştir $(15,34,35)$.

Antrenman sayısı açısından egzersiz bağımlılı̆ı devamlılık alt boyutunda antrenman sayısı 1-2 arasında olanların anlamlı şekilde daha çok egzersiz bağımlılığı riski taşıdığı görülmüştür. Buna göre antrenman sayısı az olan sporcuların hedefledikleri başarıya ulaşabilmek için egzersiz miktarıı arttırdıkları görülmektedir. Yapılan bir çalışmada egzersiz sıklığı ve günlük egzersiz süresinin egzersiz bağımlıı̆ının ortaya çıkmasında etkili olabileceği sonucuna ulaşmıştır (32). Ayrıca farklı bir çalışmada antrenman sayısı fazla sporcuların daha çok bağlanma yaşadıkları belirlenmiştir (33). Egzersiz sıklığı ile egzersiz süresini kontrol edememenin devam etmesi sonucunda egzersiz bağımlı̆ı̆ı gibi fizyolojik, psikolojik ve sosyal sorunların ortaya çıkması kaçınılmazdır.

Gelir düzeyi açısından egzersiz bağımlıı̆ı geri çekilme alt boyutunda 3001-5000 TL arasında gelire sahip sporcuların anlamlı şekilde daha çok egzersiz bağımlıı̆ı riski taşıdığı görülmüştür. Uz, yapmış olduğu çalışmada, egzersiz bağımlıı̆ı̆ riskinin en çok orta sosyo-ekonomik gelir durumundaki katılımcılarda olduğu görülmektedir (37). Yapılmış diğer çalışmalarda da benzer bulgulara rastlanmıştır $(11,38,40)$. Çalısmamızdan farkı olarak Tekkurşun-Demir ve Türkeli yapmış olduğu çalışmada gelire göre, egzersiz bağımlıı̆̆ı düzeylerinde anlamlı farklılık görülmemiştir (44).

Eğitim durumu açısından egzersiz bağımlılığı toplam puanında ve alt boyutlarında sporcuların egzersiz bağımlı̆̆ğı riski taşımadığı görülmüştür (Tablo 3). Bavlı ve arkadaşlarının dansçılar üzerine olan araştırmasında üniversite düzeyindeki sporcuların lise düzeyinde olan sporculara göre daha çok egzersiz bağımlıı̆ı riski taşıdığı tespit edilmiş̧tir (36). Uz'un, yapmış olduğu çalışmada eğitim düzeyi açısından katılımcıların semptomatik (egzersiz riski taşıyan) düzeyde oldukları görülmüştür (37). Bu çalışmalar bizim çalışmamızla farklılık göstermektedir. Düzenli olarak egzersiz yapan bireylerin genellikle lise ve üniversite eğitimi almış bireyler olduğu önceki çalışmalarda görülmüştür $(11,38)$. Oral ve Aktop çalışmasında bireylerin öğrenim düzeyleri yükseldikçe egzersize katılım oranının da yükseldiğini bildirmektedir (39). Sadıq yapmış olduğu çalışmada ise eğitim düzeyi ile egzersiz bağımlılı̆ı arasında anlamlı fark tespit etmemiştir (35). Bizim çalışmamızda da sporcuların lise ve üniversite düzeyinde olmaları literatürdeki çalışmalar ile benzer olduğunu göstermektedir.

Çalışmamızda fitness sporu yapan bireyler ile sınılandırılmıştır. Farklı branşlarda ve eşit örneklem gruplarında farkı parametreler kullanılarak egzersiz bağımlıık çalışmaları yapılabilir.

Sonuç olarak; cinsiyet, yaş, gelir düzeyi ve antrenman sayısı değişkenine göre sporcuların egzersiz bağımlıı̆ı alt boyut düzeylerinde anlamlı fark bulunurken; eğitim düzeyi açısından sporcuların egzersiz bağımlıı̆ı alt boyut düzeylerinde istatistiksel olarak anlamlı bir fark bulunmamıştır. Egzersiz bağımlılı̆ı ölçeğinin toplam puanı cinsiyet ve yaşa göre incelendiğinde anlamlı fark bulunurken, gelir düzeyi, eğitim durumu ve antrenman sayısı açısından incelendiğinde anlamlı fark bulunmamıştır. Bulgulara dayanarak erkek sporcuların ve antrenman sayısı az olan sporcuların, psikolojik veya fiziksel problemler yaşadıkları ve bu problemlerin farkında olmalarına rağmen egzersize devam ettikleri, gelir durumu 3001-5000 TL arasında olanların egzersiz yapamadığında bırakma semptomları (yorgunluk, kaygı vb.) yaşadığı söylenebilir. Yaşı 18-22 yaş arasında olanların da arzulanan etkiyi sağlamak için egzersiz miktarını arttırdığı ve problemleri olmasına rağmen egzersizi sürdürdükleri söylenebilmektedir. Egzersiz miktarını artırmak fiziksel olarak bir gelişim göstertebilir fakat aşırı egzersizin psikolojik yönden sporcuların çöküşüne sebep olduğu çoğu araştırmacılar tarafından vurgulanmaktadır. Bu sporculara aşırı egzersiz yerine kontrollü, dengeli ve doğru bir egzersiz programının daha verimli olacağı konusunda destek verilmesi gerektiği düşünülmektedir. Sporcuların amaçları doğrultusunda hareket ederken bu durumu egzersiz bağımlısı olmadan devam ettirebilmeleri için her bireye uygun egzersiz programı, hedef belirleme, kendini izleme (self-monitoring) ve sosyal destek gerektiği düşünülmektedir. Ek olarak, süreç içerisinde düzenli biçimde değerlendirme yapılması fitness yapanların gelişimini ve egzersize karşı algılarını tespit etmede önemli olacaktır. Sporculara egzersiz bağımlılık riskine dikkat etmeleri ve aşırı egzersizden kaçınarak beslenmeye yönelik düzenlemeler yapmaları önerilebilir. 


\section{Bağımlılık Dergisi - Journal of Dependence}

\section{Kaynaklar}

1. Sassatelli R. Healthy cities and instrumental leisure: the paradox of fitness gyms as urban phenomena. Modern Italy 2015; 20(3): 237-249.

2. Hausenblas AH, Giacobbi PR. Relationship between exercise dependence symptoms and personality. Pers Individ Dif 2004; 36(6): 1265-1273

3. Cicioğlu Hï, Demir GT, Bulğay C, Çetin E. Elit düzeyde sporcular ile spor bilimleri fakültesi öğrencilerinin egzersiz bağımlılı̆̆ düzeyleri. Bağımlılık Dergisi 2019; 20(1): 12-20.

4. Hamer M, Karageorghis SP, Vlachopoulos SP. Motives for exercise participation as predictors of exercise dependence among endurance athletes. J Sports Med Phys Fitness 2002; 42(2): 233-239.

5. Hausenblas AH, Downs SD. How much is too much? The development and validation of the exercise dependence scale. Psychol Health Med 2002; 17(4): 387-404.

6. Demirel HG, Cicioğlu Hi. Üst düzey sporcuların egzersiz bağımlılık düzeylerinin incelenmesi. Gaziantep Üniversitesi Spor Bilimleri Dergisi 2020; 5(3): 242-254.

7. Çakır E. Fiziksel aktivite ve egzersiz bağımlılığ. Ed. Hergüner, G. İstanbul: Her Yönüyle Spor. Güven Plus Yayınları 2019; 191-211.

8. Ackard DM, Brehm BJ, Steffen JJ. Exercise and eating disorders in college-aged women: profiling excessive exercisers. Int J Eat Disord 2002; 10: 31-47.

9. American College of Sports Medicine. ACSM's Guidelines for Exercise Testing and Prescription (6th ed.). Baltimore: Lippincott Williams \& Wilkins, 2000.

10. U.S. Department of Health and Human Services. Physical Activity and Health: A Report of the Surgeon General. Atlanta: Centers for Disease Control and Prevention, 1996.

11. Bavlı Ö, Kozanoğlu ME, Doğanay A. Düzenli egzersize katılımın egzersiz bağımlıı̆ı üzerine etkisi. Selçuk Üniversitesi Beden Eğitimi ve Spor Bilim Dergisi 2011; 13(2): 150-153.

12. Allegre B, Marc S, Pierre T, Mark G. Definitions and measures of exercise dependence. Addict Res Theory 2006; 6: 631-646.

13. Ardıç F. Egzersiz reçetesi. Turkish Journal of Physical Medicine and Rehabilitation 2014; 60(2): 1-8.

14. Polat C, Şimşek KY. Spor merkezlerindeki bireylerin egzersiz bağımlılığı düzeylerinin incelenmesi: Eskişehir ili örneği. Akademik Sosyal Araştırmalar Dergisi 2015; 3(15): 354-369.

15. Hamer M, Karageorghis Cl. Psychobiological mechanisms of exercise dependence. J Sports Sci Med 2007; 37(6): 477-484.

16. Fox K, Boutcher S. Physical Activity and Psychological Well-Being. London: Routledge, 2004; 130-153.

17. Youngman J, Simpson D. Risk for exercise addiction: a comparison of triathletes training for sprint, olympic, half-Ironman, and ıronman distance triathlons, J Clin Sport Psychol 2014; 8(1): 19-37.

18. LePage ML, Crowther JH, Harrington EF, Engler P. Psychological correlates of fasting and vigorous exercise as compensatory strategies in undergraduate women Int J Eat Disord 2008; 9(4): 423-429.

19. Prichard I, Tiggemann M. Relations among exercise type, selfobjectification, and body image in the fitness centre environment: The role of reasons for exercise. Psychol Sport Exerc 2008; 9(6): 855-866.

20. Bishop I. Health or harm? Exercise dependence and its effects on body satisfaction and self-esteem. Thesis, Windsor: Psychology of Department, University of Windsor, 2009.

21. Hausenblas HA, Downs DS. Relationship among sex, Imagery, and exercise dependence symptoms. Psychol of Addict Behav, 2002; 16: 169-172.

22. Yeltepe H, İkizler HC. Egzersiz Bağımlı̆̆g Ölçeği-21'in geçerlilik ve güvenilirlik çalışması. Bağımlıık Dergisi, 2007; 8(1): 29-35.

23. Tabachnick BG, Fidell LS. Using Multivariate Statistics, 6th Edn. Northridge. CA: California State University, 2013.

24. Diekhoff GM. Running amok: Injuries in compulsive runners, J of Sport Behav 1984; 7(3): 120-129.

25. Davis C. Weigth and diet preoccupation and addictieveness the role of exercise. Pers. Individ. Dif 1990; 11(8): 823- 827.

26. Bingöl E. Farkı branşlardaki sporcuların egzersiz bağımlıık ve psikolojik sağlamlık düzeylerinin incelenmesi. Yüksek Lisans Tezi, Muğla: Muğla Üniversitesi, 2015.

27. Yeltepe H. Egzersiz bağımlıı̆ııın tanımlanması ve Egzersiz Bağımllı̆̆ı Ölçeği-21'in geçerlilik ve güvenilirlik çalışmasının yapılması. Yüksek Lisans Tezi, İstanbul: Marmara Üniversitesi, 2005.

28. Vardar E. Egzersiz bağımlıı̆ı. Arşiv Kaynak Tarama Dergisi 2012; 21(3): 163-173. 
29. Hailey BJ, Bailey LA. Negative addiction in runners: A quantitative approach. J Sports Behav 1982; 5(3): 150 154.

30. Pierce EF, Rohaly KA, Fritchley B. Sex differences on exercise dependence for men and women in a marathon road race. Percept Mot Skills 1997; 84(3): 991-994.

31. Ségolène $P$, Philip $G$. Which sports are more at risk of physical exercise addiction: A systematic review. Addict Behav 2019; 93: 257-262.

32. Costa S, Cuzzocrea F, Hausenblas HA, et al. Psychometric examination and factorial validity of the exercise dependence scale-revised in Italian exercisers. J Behav Addict 2012; 1(4): 186-190.

33. Kayhan RF. Determining the attachment styles of football coaches to their athletes. Journal of Educational Issues 2020; 6(2): 232-248.

34. Namlı S, Demir GT, Cicioğlu Hî. Spor bilimleri fakültesi öğrencilerinin akademik odaklanma düzeyleri. Beden Eğitimi ve Spor Bilimleri Dergisi 2018; 20(4): 43-51.

35. Sadıq BJ. Investigation of the exercise dependence of athlets' kick boxing, taekwondo and muay thai. Masters thesis. Elazığ: Firat University, Institute of Health Sciences Department of Physıcal Education and Sports, 2018.

36. Bavı Ö, Işık S, Canpolat 0, et al. Dansçılarda egzersiz bağımlılığı semptomunun incelenmesi. Uluslararası Spor, Egzersiz ve Antrenman Bilimi Dergisi 2015; 1(2): 120-124.

37. Uz İ. Fitness merkezlerine düzenli katılan bireylerde egzersiz bağımlılı̆ının incelenmesi. Yüksek Lisans Tezi, Çanakkale: Çanakkale Onsekiz Mart Üniversitesi, 2015.

38. Zırhlıoğlu G. Egzersiz bağımlılı̆ının egzersiz davranış parametrelerine göre incelenmesi: Van il örneği, e-Journal of New World Sciences Academy 2011; 6(4): 214-222.

39. Oral C, Aktop A. Üniversite öğrencilerinin egzersiz öz yeterlik düzeyleri ve egzersiz davranış değişim basamaklarının incelenmesi. International Journal of Science Culture and Sport, 2014; 2(Special Issue 2): 287300.

40. Akgöl Ö. Egzersiz yapan yetişkinlerin egzersize olan bağımlılık düzeylerinin incelenmesi. Yüksek Lisans Tezi, Manisa: Celal Bayar Üniversitesi, 2019.

41. Hurst R, Hale B, Smith D, et al. Exercise dependence, social physique anxiety, and social support in experienced and Inexperienced bodybuilders and weight lifters, Br J Sports Med 2000; 34: 431-435.

42. Blaydon MJ, Lindner KJ, Kerr JH. Metamotivational characteristics of exercise dependence and eating disorders in highly active amateur sport participants. Pers Individ Dif 2004; 36: 1419-32.

43. Pierce EF. Exercise dependence syndrome in runners. Sports Med 1994; 18(3): 149-155.

44. Tekkurşun-Demir G, Türkeli A. Spor bilimleri fakültesi öğrencilerinin egzersiz bağımlılı̆ı ve zihinsel dayanıklılık düzeylerinin incelenmesi. Spor Bilimleri Araştırmaları Dergisi 2018; 4(1): 9-24.

45. Bootan JS. Kickboks, taekwondo ve muay thai sporcularının egzersiz bağımlılığının araştıııması. Yüksek Lisans Tezi, Elazığ: Fırat Üniversitesi, Sağık Bilimleri Enstitüsü, 2018. 